\title{
Cosmopolíticas da Terra: Modos de existência e resistência no Antropoceno.
}

\author{
Autora: Alyne de Castro Costa - Pontifícia Universidade Católica \\ do Rio de Janeiro
}

\section{"Nós já somos um pouco pedra"}

Alyne de Castro Costa

\author{
Carlos Jacinto Motta \\ FAPCOM - Faculdade Paulus de Comunicação \\ <carlos.motta@fapcom.edu.br>
}

Ler uma tese de doutorado em filosofia não é sempre uma tarefa agradável, porque muitas vezes o estilo acadêmico de escrita visa antes a atender aos padrões departamentais que apresentar boas ideias para serem discutidas e repercutidas. Grandes teses, com excelentes contribuições aos mais variados debates, com valiosas abordagens - as vezes ousadas até perdem-se nas estantes do fundo de bibliotecas universitárias simplesmente porque seus autores não puderam (ou não quiseram) dialogar com o grande público leitor, limitando-se a escrever aquilo que a banca de avaliação quer ler.

Não é o caso de Cosmopolíticas da Terra: Modos de existência e resistência no Antropoceno, de Alyne de Castro Costa. Esta tese de doutorado, defendida na PUC-RIO em 2019, é quase um oásis no imenso deserto de teses e dissertações estéreis produzidas aos montes nos tempos atuais. A leitura do texto nos remete a um debate urgente e inescapável e o eficiente estilo da escrita até nos faz esquecer que se trata de um documento acadêmico produzido com os rigores exigidos por um dos dois melhores programas de pós-graduação em filosofia do país. Alyne de Castro Costa mostra que possível escrever bem, segundo os doutos acadêmicos, e ainda assim apresentar suas ideias de modo a se fazer compreender bem por leitores não especializados.

No texto encontramos, desde o título, uma indicação direta do assunto principal sobre o qual a autora se debruçará, o Antropoceno. Mas não pense o leitor que se trata de uma abordagem puramente teórica e conceitual, baseada em uma revisão bibliográfica exaustiva. Não. O que encontramos é uma lúcida e consistente chamada à responsabilidade quanto às questões mais urgentes que a humanidade enfrenta, a saber, o risco de tornar o planeta inabitável para os humanos devido ao "devir louco generalizado" (p. 20) que produz a catástrofe ecológica que temos presenciado. É urgente a adoção de uma nova política (ambiental, existencial etc.) que, diz a autora, deverá ser chamada de cosmopolítica.

Para dar conta da tarefa proposta, Alyne de Castro Costa apresenta, no Capítulo 1, um panorama geral da situação em que o planeta se encontra. Vale ressaltar que a autora usa tanto fontes documentais de relevância acadêmica e científica como relatos em primeira pessoa de habitantes dos ecossistemas icônicos, com a Amazônia, fornecendo uma visão ao mesmo tempo técnica e humanista ao assunto. O resultado é excelente e mostra que as questões ambientais não podem mais ser tratadas numa relação entre partes e o todo. Na verdade, destaca 
ela, as ações humanas produzem impactos estruturais no planeta como um todo e pensar apenas nos problemas localizados não ajuda na compreensão exata do problema que enfrentamos.

O Capítulo 2 discute o conceito de Antropoceno, caracterizado como uma etapa geológica marcada pelo impacto geológico e ecológico da humanidade no planeta. Em outras palavras, nesse período as atividades humanas provocam mudanças sistêmicas no planeta e "afetam fluxos biogeoquímicos em escala global, ameaçando o funcionamento do sistema da Terra como um todo de formas ainda não completamente compreendidas" (p. 86). Com a ajuda de pensadores como Latour, Deleuze, Viveiros de Castro, Danowski, entre outros, a autora discute filosoficamente o conceito de antropoceno ao mesmo tempo que afirma a necessidade de resistência e defesa da vida por meio da criação dos meios necessários às soluções urgentes. O capítulo é o mais denso e o mais "filosófico", além de apresentar o maior número de pensadores e uma grande variedade de ideias. Isso pode causar uma sensação de superficialidade ou de falta de foco no assunto central, mas ao final vemos que cada ideia apresentada contribui um pouco para a formação da ideia geral de resistência, central para a proposta da autora.

No terceiro e último capítulo, Alyne de Castro Costa se dedica a uma abordagem, digamos, mais especulativa e ontológica ao tratar de caracterizar os Terranos, o outro povo envolvido no debate aqui apresentado e que se apresenta como a possibilidade de criação da resistência (re-existência) ao fim anunciado. Segundo a autora, "não se trata aqui de determinar uma identidade fixa atribuível a alguns indivíduos que compartilham certas características comuns [...] A investigação sobre os Terranos, ao contrário, deve consistir no experimento especulativo de compor um povo a partir das variadas maneiras existentes e possíveis de se sentir ligado à Terra, de a ela pertencer, de ser Earthbound" (p. 170). Esse novo "povo" será responsável por criar outras formas de relação entre os seres e a Terra, superando o antropocentrismo e suas consequências destruidoras.

A leitura da tese é mais que recomendável. Com um teor escatológico e ao mesmo tempo esperançoso, a tese de Alyne de Castro Costa surpreende por ser consistente e palatável, profunda e compreensível, levando o leitor a um mergulho em algumas das mais sérias questões existenciais e ambientais por meio de uma discussão filosófica que mais parece um diálogo aberto e franco. Ler este texto nos ajuda a compreender de modo muito profundo as questões relacionadas ao desastre ambiental que já vivemos e nos oferece um caminho possível de superação de tais adversidades, além de alimentar a esperança, tão maltratada em nossos dias.

Data do recebimento: 03/11/2021

Data do aceite: $03 / 11 / 2021$

Dados do autor:

\section{Carlos Jacinto Motta}

Lattes: http://lattes.cnpq.br/0981794152833598

Professor de Filosofia na FAPCOM - Faculdade Paulus de Comunicação. É doutor em Filosofia pela PUC-SP. Graduado em Filosofia pela Universidade Metodista de São Paulo (2000) e Mestre em Filosofia pela Pontifícia Universidade Católica do Rio de Janeiro (2004). Atualmente, além da docência atua como coordenador adjunto do projeto de extensão Fora da escola na Universidade Federal do ABC além de projetos de pesquisa de Filosofia, com ênfase em Teoria do conhecimento, Filosofia Moderna e Filosofia da Ciência e Educação com ênfase em formação de professores. 